\title{
Kesesuaian Wisata Bahari Berdasarkan Indeks Tutupan Karang di Perairan Pantai Teluk Lombok Kecamatan Sangatta Selatan
}

\author{
Muhammad Hirwan Wahyudi ${ }^{1}$ dan Anshar Haryasakti ${ }^{2}$ \\ ${ }^{1,2}$ Sekolah Tinggi Pertanian Kutai Timur, Sangatta, Kutai Timur, Kalimantan Timur \\ ${ }^{1}$ Email: hirwan@stiperkutim.ac.id \\ 2 Email: haryasaktia@yahoo.com
}

\begin{abstract}
Lombok Bay as a tourist destination which has a stretch of coral reef that can be used one of a maritme tourism object. Research aims were: (1) To determine the condition of coral reefs in Lombok Bay beach, (2) To determine the suitability index value of snorkeling and diving tourism in Lombok Bay. The research was conducted June up to August 2020 in Lombok Bay waters, Sangkima Village, South Sangatta Sub-district. Line Intercept Transect method were used for retrieved of coral reef data. The results showed that the condition of coral reefs was still classified as good at station I with a percentage $60,14 \%$, station II was in the bad category with a percentage $9,58 \%$, station III was a medium category with a percentage $25,06 \%$. Lombok coastal Bay waters can still be used as a snorkeling and diving tourism location

Keywords: Coral Reef, Snorkeling Tourism, Diving Tourism, Line Intercept Transect, Coral Reef Cover Percentage.
\end{abstract}

\begin{abstract}
ABSTRAK
Teluk Lombok sebagai destinasi wisata yang memiliki hamparan terumbu karang yang dapat dijadikan salah satu objek wisata bahari. Tujuan Penelitian ini : (1) Untuk mengetahui kondisi terumbu karang yang ada di pantai teluk Lombok, (2) Untuk mengetahui nilai indeks kesesuaian wisata snorkling dan diving di Teluk Lombok. Penelitian ini dilaksanakan pada bulan Juni sampai dengan Agustus 2020 di perairan Teluk Lombok desa Sangkima Kecamatan Sangatta Selatan. Pengambilan data terumbu karang mengunakan metode Line Intercept Transect. Hasil penelitian menunjukkan bahwa kondisi terumbu karang pada stasiun I masih tergolong baik dengan Presentase $60,14 \%$, stasiun II terumbu karang tergolong dalam kategori buruk dengan presentase $9,58 \%$, stasiun III masuk dalam ketegori sedang dengan presentase $25,06 \%$. Perairan pantai teluk lombok masih dapat dijadikan lokasi wisata snorkling dan diving.

Kata kunci: Kondisi Terumbu Karang, Indeks Kesesuaian Wisata Snorkling, Indeks Kesesuaian Wisata Diving, Line Intercept Transect, Persentase Tutupan Terumbu Karang
\end{abstract}

\section{Pendahuluan}

Indonesia dengan panjang garis pantai $108.000 \mathrm{~km}^{2}$ memiliki hamparan terumbu karang yang sangat luas yang tersebar di 17.504 pulau. Purnawarman (2020) Sebagai benua maritim, terdapat berbagai macam jenis karang yang hidup disepanjang perairan Indonesia yang membentuk sebuah ekosistem terumbu karang yang sangat indah, menjadikan setiap daerah yang memiliki perairan laut terdapat terumbu karang yang berbeda-beda. Terumbu karang merupakan sebuah ekosistem perairan di Indonesia yang bersimbiosis dengan zooxantellae. Polip merupakan satu individu dari karang sedangkan koloni adalah gabungan dari beberapa individu karang (Rembet, 2012). 
Terumbu karang selain menjadi tempat dari ekosistem juga sebagai pelindung abrasi pantai, (Rondonuwu et al., 2013). Menurut Suharsono (2008), ada enam jenis tipe dari pertumbuhan karang. Perkembangan terumbu karang dipengaruhi oleh beberapa faktor lingkungan seperti, intensitas cahaya, suhu, salinitas, kedalaman, kecerahan, arus dan gelombang. Rani et al., (2015) menyatakan terumbu karang dapat tumbuh dan berkembang dengan baik pada kedalaman $<25 \mathrm{~m}$, pada kedalaman diatas $25 \mathrm{~m}$ maka cahaya sinar matahari tidak akan mampu menembus kedalam tersebut sehingga terumbu karang tidak akan dapat berfotosintesis yang menyebabkan karang tersebut tidak dapat berkembang. Keruhnya perairan yang disebabkan oleh terlarutnya partikel dari daratan yang terbawa melalui aliran sungai yang bermuara dilaut juga ikut mempengaruhi intensitas cahaya yang masuk kedalam perairan (Tanto \& Kusumah, 2016).

Salim (2012) mengatakan ketidaksesuaian suhu dan unsur hara di perairan akan menyebabkan kematian pada terumbu karang. Kenaikan suhu permukaan bumi yang semakin tahun semakin meningkat menyebabkan tingginya tingkat pemutihan pada terumbu karang. Selain itu menurut Supriharyono (2007) peristiwa alam seperti gempa bumi, badai dan peristiwa Elnino juga dapat merusak terumbu karang. Terumbu karang dapat hidup dan berkembang dengan baik pada kisaran salinitas 30-35\%. Dahuri (2003), sedangkan menurut Nontji (2002) Bahwa hewan karang mempunyai kemampuan mentoleransi salinitas dari 27-40\%. Selain beberapa parameter tersebut sekarang ini perkembangan terumbu karang juga dipengaruhi oleh aktifitas manusia (Burke et al., 2002).

Kabupaten Kutai Timur merupakan salah satu kabupaten yang berada di wilayah provinsi Kalimantan Timur. Luas wilayah Kabupaten Kutai Timur sebesar 35.747,50 Km², terdiri dari 18 kecamatan dengan 141 desa, memiliki jumlah penduduk sebanyak 376.111 jiwa dengan pertumbuhan penduduk setiap tahunnya berkisar antara 3,90\% - 4,07\%. Secara geografis pantai Teluk Lombok berada dalam Desa Sangkima Kecamatan Sangatta Selatan terletak pada posisi $117^{\circ} 30^{\prime} 51^{\prime \prime} \mathrm{E}-0^{\circ} 22^{\prime} 45^{\prime \prime} \mathrm{N}$ dengan luas wilayah 6.025,5 Ha. Bentuk permukaan tanah desa Sangkima diukur dari permukaan laut dengan ketinggian tanah 0-50 m dpl. Suhu udara rata-rata $29^{\circ} \mathrm{C}$. Curah hujan berkisar antara 110 $\mathrm{mm}$ sampai $114 \mathrm{~mm}$ pertahun. Secara geografis Sangkima memiliki batas-batas wilayah sebagai berikut (Badan Pusat Statistik, 2020).

- Sebelah Utara : Desa Sangata Selatan

- Sebelah Selatan : Desa Teluk Singkima

- Sebelah Barat: Desa Sangatta Selatan

- Sebelah Timur : Selat Makasar

Wilayah Kabupaten Kutai Timur terkenal dengan wisata alamnya termasuk dalam satu kawasan yaitu kawasan Taman Nasional Kutai (TNK). Pantai Teluk Lombok terletak 
di Desa Sangkima yang berada di Kecamatan Sangatta Selatan. Kegiatan wisata sudah lama berkembang di pantai Teluk Lombok yang memiliki panjang garis pantai mencapai dua Km. Pantai Teluk Lombok sangat diminati masyarakat untuk berwisata, dengan berbagai wahana pendukung seperti banana boat, play fish, kano, jet sky, hamparan pasir putih yang sangat cocok untuk berjemur dan bermain anak-anak, serta hamparan terumbu karang yang berpotensi sebagai wisata bahari seperti snorkling dan diving. Pantai Teluk Lombok merupakan daerah pesisir yang memiliki potensi sumberdaya laut yang selama ini dimanfaatkan oleh masyarakat sekitar untuk berbagai macam kegiatan termasuk penangkapan dan pariwisata. Semakin berkembangnya kegiatan pariwisata di daerah tersebut dan kegiatan lain maka akan terjadi berbagai macam perubahan pada wilayah itu, untuk mengimbangi perkembangan yang terjadi di wilayah tersebut maka diperlukan berbagai macam data terkini mengenai sumberdaya yang ada di daerah pantai Teluk Lombok yang nantinya akan dijadikan data untuk pengelolaan yang berwawasan lingkungan, sehingga dapat mempertahankan dan mengembangkan potensi yang ada secara optimal dan berkelanjutan. Berdasarkan potensi yang dapat dikembangkan mengenai terumbu karang di pesisir pantai Teluk Lombok. Maka untuk alasan tersebut, perlu dilakukan penelitian mengenai kesesuaian wisata bahari berdasarkan indeks tutupan karang di Perairan Pantai Teluk Lombok Kabupaten Kutai Timur. Untuk mengkaji kondisi terumbu karang dalam kaitannya sebagai penilaian indeks kesesuaian wisata snorkling dan diving pantai di Teluk Lombok

\section{Metode Penelitian}

\section{Lokasi dan Waktu Penelitian}

Penelitian ini dilaksanakan di perairan Teluk Lombok Desa Sangkima Kecamatan Sangatta Selatan Kabupaten Kutai Timur. Pengambilan data dilaksanakan pada bulan Juni-Agustus 2020. Objek penelitian ini menitik beratkan pada kondisi tutupan terumbu karang sebagai potensi pengembangan wisata bahari di perairan pantai Teluk Lombok Kabupaten Kutai Timur. Sampel penelitian adalah terumbu karang dan kondisinya yang berpotensi untuk lokasi pariwisata di daerah perairan pantai Teluk Lombok Metode survei untuk pengambilan data adalah metode Line Intercept Transec (LIT).

\section{Alat dan Bahan}

1. Alat ukur roll meter 100 meter yang digunakan untuk mengukur panjang transek dan kedalaman perairan

2. Alat scuba diving (merk Cressy) digunakan untuk membantu dalam penyelaman

3. Lifeform dan alat tulis untuk mencatat data di dalam air

4. Kamera bawah air ( Nikon colpix W300) digunakan untuk dokumentasi

5. Perahu (ketinting 5PK merek yamaha) untuk transportasi 
ISSN 2354-7251 (print)

6. Layang-layang arus digunakan untuk mengukur kecepatan arus

7. Hand refraktometer digunakan untuk mengukur salinitas

8. GPS Garmin 60CSx digunakan untuk menentukan titik koordinat lokasi pengambilan data penelitian

9. Thermometer untuk mengukur suhu

10. Secchi disc untuk mengukur kecerahan

11. Stop watch untuk mengukur waktu

12. Daftar pertanyaan (kuesioner)

13. Komputer untuk mengolah data

\section{Papan scaner}

\section{Prosedur Penelitian}

Pada perairan Teluk Lombok Kabupaten Kutai Timur ditentukan titik-titik survei (stasiun) yang dianggap mewakili kondisi dari sebaran terumbu karang yang ada. Guna mendapatkan data sebaran karang, maka dilakukan penandaan koordinat pada peta citra yang diestimasi sebagai lokasi keberadaan terumbu karang yang kemudian dilakukan ground check pada titik koordinat tersebut pada saat survei di lapangan dan juga menggali informasi dari masyarakat setempat tentang lokasi sebaran terumbu karang yang ada di Teluk Lombok. Semua titik koordinat di inpit kedalam GPS yang dijadikan sebagai titik lokasi penelitian. Penelitian ini juga menggunakan metode survei. Dalam pengambilan data terumbu karang dilakukan dengan memakai metode Line Intercept Transect (LIT). Panduan dalam pengambilan data menggunakan panduan kategori, kode dan keterangan menurut English et al., (1994). Untuk mengetahui kondisi oseanografi perairan Teluk Lombok dilakukan pengukuran beberapa parameter secara langsung di lapangan yaitu suhu, salinitas, kecerahan, kecepatan arus. Setiap parameter diukur pada setiap lokasi pengambilan data.

\section{Analisis Data}

Persentase penutupan karang untuk masing-masing jenis lifeform, persentase karang keras hidup, serta indeks kematian karang dihitung dengan menggunakan rumus : (Jompa \& Pet-Soede, 2002).

1. Persentasi penutupan per lifeform $\alpha$

$$
\text { Persen Cover } \alpha=\frac{\sum \text { Panjang } \alpha}{\sum \text { panjang keseluruhan transek }} \times 100 \%
$$

Keterangan : $\alpha$ adalah jenis lifeform Klkarang atau kategori tertentu 
2. Menentukan katagori kondisi terumbu karang dengan mengacu pada kriteria berikut :

Tabel 1. Kriteria baku kerusakkan terumbu karang

\begin{tabular}{lll}
\hline Kategori kondisi terumbu karang & \multicolumn{1}{c}{$\begin{array}{c}\text { Persentase penutupan karang keras hidup } \\
\text { (Hard Coral Live Coverage) }\end{array}$} \\
\hline 1. & Sangat Baik & $\geq 75 \%$ \\
2. & Baik & $50 \%-<75 \%$ \\
3. & Sedang/Moderat & $25 \%-<50 \%$ \\
4. & Buruk/Rusak & $<25 \%$ \\
\hline
\end{tabular}

Sumber : Hill \& Wilkinson (2004)

3. Indeks kematian terumbu karang (Coral mortality index)

$$
\mathrm{CMI}=\text { Persentasi penutupan } \frac{(\text { Dead Coral }+\mathrm{R})}{(\text { Hard Coral }+ \text { Dead Coral }+\mathrm{R})}
$$

Keterangan: Dengan kisaran kategori rendah ( $\mathrm{CMI}<25 \%)$, sedang $(\mathrm{CMI} 25 \%<$ $50 \%$ ), tinggi (CMI 50\%

$-<70 \%)$, dan sangat tinggi (CMI $\geq 75 \%)$

Analisis kesesuaian wisata menggunakan matriks kesesuaian disusun berdasarkan kepentingan setiap parameter untuk mendukung kegiatan pada daerah tersebut. Matriks kesesuaian untuk wisata bahari kategori wisata snorkeling dan diving dapat dilihat pada tabel 2 berikut:

Tabel 2. Matriks kesesuaian lahan untuk ekowisata bahari kategori wisata snorkling dan diving

\begin{tabular}{|c|c|c|c|c|c|c|c|c|}
\hline No & Parameter & Bobot & $\begin{array}{l}\text { Kategori } \\
\text { S1 }\end{array}$ & Skor & $\begin{array}{l}\text { Kategori } \\
\text { S2 }\end{array}$ & Skor & $\begin{array}{l}\text { Kategori } \\
\text { S3 }\end{array}$ & Skor \\
\hline$\overline{1}$ & $\begin{array}{l}\text { Kecerahan perairan } \\
(\%)\end{array}$ & 5 & $>80$ & 3 & $50-80$ & 2 & $20-<50$ & 1 \\
\hline 2 & $\begin{array}{l}\text { Tutupan karang } \\
(\%)\end{array}$ & 5 & $>75$ & 3 & $>50-75$ & 2 & $25-50$ & 1 \\
\hline 3 & Jumlah lifeform & 3 & $>12$ & 3 & $<7-12$ & 2 & $04-07$ & 1 \\
\hline 4 & Kedalaman (m) & 1 & $02-15$ & 3 & $15-20$ & 2 & $>20-30$ & 1 \\
\hline 5 & Arus (cm/dt) & 1 & $0-15$ & 3 & $>15-30$ & 2 & $>30-50$ & 1 \\
\hline
\end{tabular}

Keterangan : - Jumlah $=$ Skor $\mathrm{x}$ bobot - Nilai maksimum $=45$.

Analisis kesesuaian lahan dilakukan untuk mengetahui kesesuaian kawasan untuk pengembangan wisata. Ini dilakukan untuk melihat kemampuan suatu wilayah dalam mendukung kegiatan yang dilakukan di kawasan tersebut. Rumus yang digunakan untuk kesesuaian wisata bahari, Yulianda (2007) adalah sebagai berikut :

$$
\mathrm{IKW}=\Sigma[\mathrm{Ni} / \mathrm{Nmaks}] \times 100 \%
$$

Keterangan: $\mathrm{IKW}=$ Indeks kesesuaian wisata

$\mathrm{Ni}=$ Nilai parameter Ke-l (bobot $\mathrm{x}$ skor)

Nmaks = Nilai maksimum dari suatu kategori wisata.

S1 = sangat sesuai, dengan nilai $75-100 \%$

S2 = Cukup sesuai, dengan nilai $50-<75 \%$

S3 = Sesuai bersyarat, dengan nilai $25-<50 \%$

$\mathrm{N} \quad=$ Tidak sesuai, dengan nilai $<25$ 


\section{Hasil Dan Pembahasan}

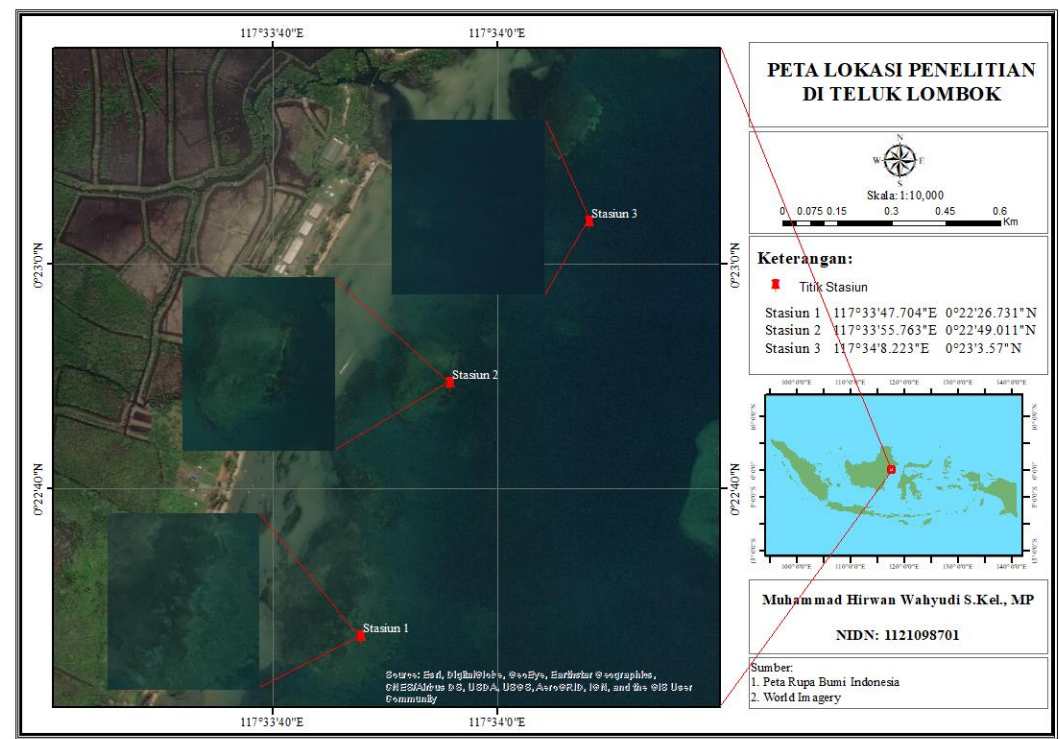

Gambar 1. Lokasi Penelitian Digitasi

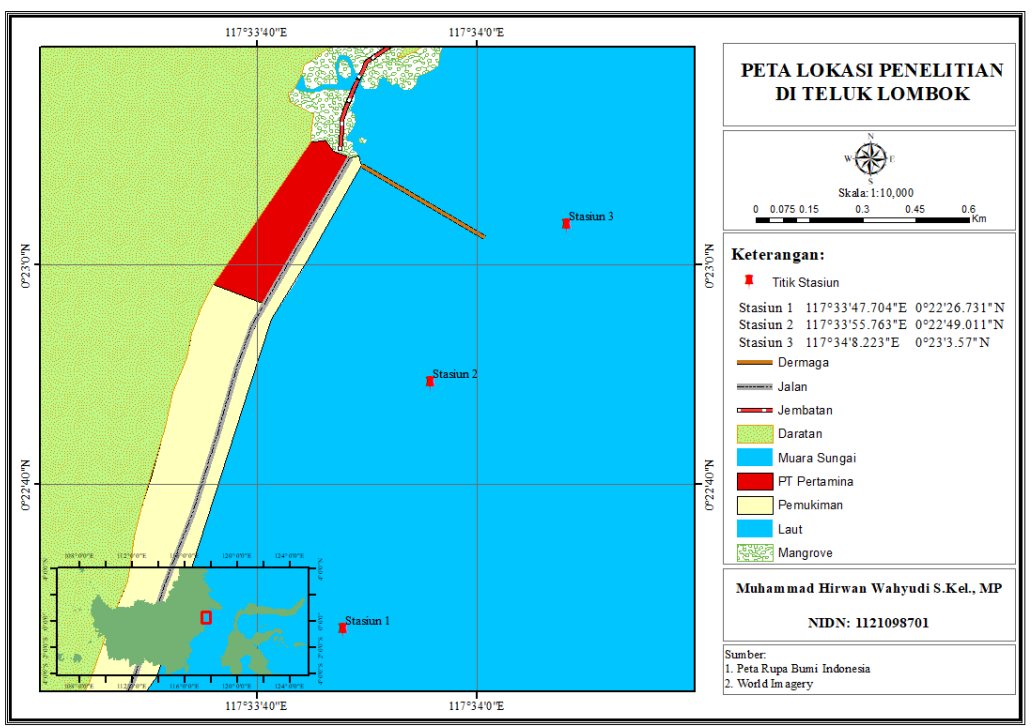

Gambar 2. Lokasi Penelitian

Lokasi pengamatan diambil dari tiga titik yang berbeda. Stasiun I berada pada titik koordinat $117^{\circ} 33^{\prime} 47.704^{\prime \prime}$ E - $0^{\circ} 22^{\prime} 26,731^{\prime \prime}$ N. Stasiun II pada koordinat $117^{\circ} 33^{\prime} 55,763^{\prime \prime}$ E - $0^{\circ} 22^{\prime} 49,011^{\prime \prime} \mathrm{N}$ dan stasiun III terletak di koordinat $117^{\circ} 34^{\prime} 8,223^{\prime \prime} \mathrm{E}-0^{\circ} 23{ }^{\prime} 3,57^{\prime \prime} \mathrm{N}$. Di tiga stasiun tersebut selain mengamati terumbu karang, juga melakukan pengukuran kualitas perairan yang mempengaruhi kondisi terumbu karang. Setelah penelitian yang dilakukan di tiga stasiun hasil pengukuran parameter kualitas perairan dapat dilihat pada tabel 3 berikut: 
Tabel 3. Hasil pengukuran parameter fisika oceanografi di Teluk Lombok

\begin{tabular}{lcccc}
\hline Parameter & Satuan & \multicolumn{3}{c}{ Stasiun Pengamatan } \\
\hline Suhu & & Stasiun 1 & Stasiun 2 & Stasiun 3 \\
Salinitas & ${ }^{\circ} \mathrm{C}$ & 29 & 29 & 29 \\
Kecerahan & $\%$ oo & 33 & 35 & 35 \\
Kecepatan Arus & $\%$ & 85 & 83 & 96 \\
Kedalaman & $\mathrm{cm} / \mathrm{s}$ & 12 & 16 & 15,8 \\
\hline
\end{tabular}

Berdasarkan hasil pengukuran di setiap stasiun pengamatan di dapatkan nilai dari ketiga lokasi suhu yang sama yaitu $29^{\circ} \mathrm{C}$, nilai yang sangat baik untuk pertumbuhan terumbu karang. Nybakken (1992) suhu optimal untuk terumbu karang $23-25^{\circ} \mathrm{C}$ dengan toleransi $36-40^{\circ} \mathrm{C}$. Patty \& Akbar (2018) suhu di perairan Ternate, Tidore dan sekitarnya berada pada $29,2-30,4^{\circ} \mathrm{C}$. Perairan yang memiliki suhu seperti ini yang disukai terumbu karang karena terumbu karang dapat berkembang pada suhu seperti ini. Organisme terumbu karang akan mati ketika terjadi kenaikan/penurunan salinitas secara ekstrim. Hasil pengukuran salinitas pada stasiun I sebesar $33 \%$, sementara untuk stasiun II dan III nilai yang didapatkan sama yaitu sebesar 35\%. Cahaya sangat diperlukan untuk pertumbuhan terumbu karang (Supriharyono, 2007). Pada stasiun I dan III kecerahan yang diperoleh sama yaitu 6 meter, sementara pada stasiun II kecerahan yang diperoleh adalah 5 meter. Kecerahan air laut menurut standar baku mutu harus lebih dari 5 meter. Dari hasil tersebut menunjukkan bahwa syarat standar baku dapat terpenuhi pada semua stasiun. Berdasarkan hasil pengukuran yang dilakukan di pantai Teluk Lombok diperoleh kecepatan arus pada stasiun I yaitu $12 \mathrm{~cm} / \mathrm{s}$, stasiun II yaitu $16 \mathrm{~cm} / \mathrm{s}$ dan stasiun III yaitu $15,8 \mathrm{~cm} / \mathrm{s}$. Yulianda (2007) matrik kesesuaian lahan ekowisata bahari berkisar 0-15 cm/s. Arus sangat penting bagi kehidupan terumbu karang, karena dengan adanya arus maka $\mathrm{O}^{2}$ akan tersedia bagi terumbu karang. Pengaruh cahaya yang sangat erat hubungannya dengan pertumbuhan terumbu karang, maka faktor kedalaman juga membatasi kehidupan binatang karang. Hasil dari pengamatan yang dilakukan dari ketiga stasiun maka nilai rata-rata kedalaman mencapai 6,4 meter. Pada stasiun I mencapai kedalaman hingga 7 meter, sedangkan di stasiun II mencapai 6 meter dan stasiun III mencapai 6,2 meter. Hewan karang tidak dapat berkembang di perairan yang lebih dalam dari 70 meter, intensitas cahaya akan semakin berkurang seiring dengan bertambah dalamnya kedalaman suatu perairan. 
Tabel 4. Persentase Hard Coral Life pada Lifeform di Stasiun I

\begin{tabular}{lcc}
\hline Kategori Lifeform Hard Coral Life & Kode Lifeform & Stasiun I \\
\hline Hard Coral & ACB & \\
& ACD & 6,18 \\
& ACE & 5,06 \\
Acropora & ACS & 3,68 \\
& ACT & 2,56 \\
& CHL & 24,22 \\
Non Acropora & CMR & 2,42 \\
Total Penutupan (\%) & CM & 0,56 \\
Kepmen LH No. 4, 2001 & CS & 12,44 \\
\hline
\end{tabular}

Pengamatan terumbu karang dengan Metode LIT hanya dilakukan 1 (satu) kali pada setiap stasiun pengamatan yaitu ada kedalaman 7 meter. Berdasarkan hasil penelitian kondisi penutupan terumbu karang di stasiun I sebesar 60\%. Pada stasiun ini menunjukkan bahwa kondisi terumbu karang dapat dikatakan dalam kondisi baik sesuai riteria baku kerusakkan terumbu karang yang mengacu pada kepmenneg LH No.4 tahun 2001. Karena hasil dari perhitungan (HCL) Hard Coral Life, menunjukkan nilai persentase $60,14 \%$. Karang yang mendominasi pada stasiun ini adalah acropora tabulate dengan nilai presentase sebesar $24,22 \%$. Hal ini disebabkan pada lokasi tersebut habitatnya masih alami, itensitas cahaya yang tinggi dan kurangnya aktivitas manusia. Muqsit et al., (2016) tingginya penutupan karang keras menandakan terumbu karang dalam kategori baik.

Tabel 5. Komponen Hard Coral Life pada Lifeform di Stasiun II

\begin{tabular}{lcc}
\hline Kategori Lifeform Hard Coral Life & Kode Lifeform & Stasiun II \\
\hline Hard Coral & ACB & 0 \\
& ACD & 2,02 \\
& ACE & 0 \\
Acropora & ACS & 0 \\
& ACT & 2,56 \\
& CHL & 0 \\
Non Acropora & CMR & 0,96 \\
Total Penutupan (\%) & CM & 4,04 \\
\hline Kepmen LH No. 4, 2001 & CS & 0 \\
\hline
\end{tabular}

Tutupan terumbu karang pada stasiun II memiliki nilai yang lebih rendah dibandingkan dengan stasiun I. Standar baku mutu terumbu karang menurut Kepmen LH No.4 tahun 2001 pada stasiun II masuk dalam kategori rusak dengan presentasi 9,58\%. Koroy et al., (2020) mengatakan persentasi tutupan terumbu karang hidup di kisaran 10,8$20,52 \%$ termasuk dalam kategori buruk. Jumlah keanekaragaman jenis pertumbuhan karang pada stasiun ini relatif sedikit, sehingga penutupannya sangat kecil. Pada stasiun 
II jenis terumbu karang yang mendominasi adalah jenis coral masive dengan memiliki nilai persentase 4,04 sedangkan jenis karang yang memiliki nilai persentase terendah adalah jenis coral mushroom, karakteristik coral massive tumbuh pada daerah yang berarus dan bergelombang. Kerusakan terumbu karang pada daerah ini lebih tinggi dibandingkan stasiun I, baik yang terjadi secara alami seperti kenaikan suhu permukaan (Global Warming), maupun oleh aktivitas manusia seperti illegal fishing. Daerah ini juga memiliki kondisi perairan yang landai dan tenang, sehingga sering digunakan oleh wisatawan untuk bermain seperti permainan banana boad dan permainan air lainnya. Kerusakan ini pada umumnya disebabkan karena terumbu karang tertutupi lumut dan sedimen dan ada juga yang mengalami pemutihan (coral bleaching) dan juga dijumpai patahan-patahan terumbu karang (rubble). Jubaedah \& Anas (2019) mengatakan kenaiakn suhu air laut yang menyebabkan bleaching pada terumbu karang dan aktifitas manusia.

Tabel 6. Komponen Hard Coral Life pada Lifeform di Stasiun III

\begin{tabular}{lcc}
\hline Kategori Lifeform Hard Coral Life & Kode Lifeform & Stasiun II \\
\hline Hard Coral & ACB & 7,66 \\
& ACD & 0,64 \\
& ACE & 0 \\
Acropora & ACS & 3,08 \\
& ACT & 6,2 \\
& CHL & 0 \\
Non Acropora & CMR & 0 \\
Total Penutupan (\%) & CB & 5,36 \\
Kepmen LH No. 4, 2001 & CS & 2,12 \\
\hline
\end{tabular}

Stasiun III menunjukan kondisi terumbu karang masuk dalam katagori sedang dengan nilai persentase $25,06 \%$ dimana pada stasiun III jenis terumbu karang yang mendominasi adalah acropora branching dengan memiliki nilai persentase 7,66 sedangkan nilai persentase terumbu karang terendah adalah jenis acropora digitate dengan nilai persentase 0,64 . Hasil pengukuran pada stasiun I parameter kecepatan arus, kedalaman dan jumlah lifeform tergolong kategori sangat sesuai. Sedangkan parameter kecerahan dan tutupan karang tergolong kategori cukup sesuai. Nilai indeks kesesuaian wisata yang diperoleh pada stasiun I yaitu 93,33\% kategori S1 (sangat sesuai). Nilai kesesuaian lahan untuk ekowisata bahari pada stasiun I yang diperoleh tergolong tinggi (sangat sesuai) dan nilai parameter kesesuaian yang diukur seperti parameter kecepatan arus yang tidak terlalu kuat sehingga dapat memberikan rasa nyaman dan aman untuk wisatawan melakukan wisata snorkling dan diving. Tutupan karang hidup masih tergolong besar, namun jika terumbu karang dijaga dan diperbaiki dengan baik maka peluang tutupan karang tumbuh baik akan semakin besar. Hal ini akan menambah nilai keunikan dan keindahan pada wisata snorkling dan diving. 
Hasil pengukuran pada stasiun II indeks kesesuaian wisata snorkling dan diving kawasan terumbu karang merupakan perhitungan seluruh kriteria terkait dengan ekowisata snorkling dan diving terumbu karang dengan kriteria yang telah ditentukan. Dalam perhitungan indeks kesesuaian yang dipakai menurut Yulianda (2007), total keseluruhan penjumlahan bobot $x$ skor kriteria dibagi dengan nilai maksimun yaitu 45 dan kemudian dikalikan 100\%, sehingga didapat hasil persentase kesesuaian wisata. Pada penelitian ini persentase IKW yaitu $51,11 \%$ yang merupakan persentase cukup sesuai (S2). Untuk stasiun ini menurut IKW memang sesuai untuk wisata snorkling dan diving akan tetapi berdasarkan standar baku mutu terumbu karang menurut Kepmen LH No.4 tahun 2001 pada stasiun II masuk dalam kategori rusak dengan presentasi 9,58\%. Maka area ini harus dilakukan upaya rehabilitasi terhadap terumbu karang yang ada. Berdasarkan hal tersebut lokasi ini tidak bisa dijadikan wisata snorkling dan diving sebelum dilakukan rehabilitasi dan pemulihan terhadap terumbu karang yang terdapat pada lokasi II ini.

Hasil pengukuran pada stasiun III parameter kedalaman dan jumlah lifeform tergolong kategori cukup sesuai dengan nilai IKW sebesar 62,22\%. Sedangkan nilai CMI sebesar 25,06 dengan kategori sedang/moderat. Pada lokasi III masih dapat dijadikan lokasi wisata snorkling dan diving dengan syarat lokasi ini harus dilakukan rehabilitasi dan pemulihan terumbu karang untuk mengembalikan karang-karang yang sebagian sudah rusak dengan mengedukasi pengelola wisata dan wisatawan untuk bersama-sama menanam karang di salah satu kegiatan berwisatanya.

Tabel 7. Nilai kesesuaian lahan untuk ekowisata bahari kategori wisata snorkling dan diving

\begin{tabular}{|c|c|c|c|c|c|c|c|c|c|c|c|}
\hline \multirow{2}{*}{ No } & \multirow{2}{*}{ Parameter } & \multirow{2}{*}{ Bobot } & \multicolumn{2}{|c|}{ Stasiun 1} & \multicolumn{4}{|c|}{ Stasiun 2} & \multicolumn{3}{|c|}{ Stasiun 3} \\
\hline & & & Hasil & Skor & $\mathrm{Ni}$ & Hasil & Skor & $\mathbf{N i}$ & Hasil & Skor & $\mathbf{N i}$ \\
\hline 1 & Kecerahan perairan(\%) & 5 & 85,7 & 3 & 15 & 100 & 3 & 15 & 96,7 & 3 & 15 \\
\hline 2 & Tutupan Karang (\%) & 5 & 60,14 & 3 & 15 & 9,58 & 0 & 0 & 25,06 & 1 & 5 \\
\hline 3 & Jumlah Lifeform & 3 & 9 & 2 & 6 & 4 & 1 & 3 & 6 & 1 & 3 \\
\hline 4 & Kedalaman(M) & 1 & 7 & 3 & 3 & 6 & 3 & 3 & 6,2 & 3 & 3 \\
\hline 5 & Arus (cm/detik) & 1 & 12 & 3 & 3 & 16 & 2 & 2 & 15,8 & 2 & 2 \\
\hline \multicolumn{3}{|c|}{ Total } & & & 42 & & & 23 & & & 28 \\
\hline \multicolumn{3}{|c|}{ Indeks kesesuaian wisata (\%) } & & & 93.33 & & & 51.11 & & & 62.22 \\
\hline \multicolumn{3}{|c|}{ Tingkat Kesesuaian } & & & S1 & & & S2 & & & S2 \\
\hline
\end{tabular}

\section{$4 \quad$ Kesimpulan}

Kondisi terumbu karang di pantai Teluk Lombok pada masing-masing stasiun berbeda. Pada stasiun I kondisi terumbu karang masih tergolong baik dengan Presentase $60,14 \%$. Sedangkan pada stasiun II terumbu karang tergolong dalam kategori buruk dengan presentase $9,58 \%$. Sementara pada stasiun III masuk dalam ketegori sedang dengan presentase $25,06 \%$. Nilai indeks kesesuaian wisata pada stasiun I tergolong dalam kategori sangat sesuai dan dapat dijadikan lokasi wisata snorkling dan diving. Nilai indeks kesesuaian wisata pada stasiun II tidak bisa dijadikan wisata snorkling dan diving 
karena nilai tutupan terumbu karang hidupnya sangat rendah yaitu 9,58\% yang termasuk dalam kategori rusak/buruk dan pada stasiun III masih dapat dijadikan lokasi wisata snorkling dan diving dan dengan syarat.

\section{Daftar Pustaka}

Badan Pusat Statistik. (2020). Sangatta Selatan Dalam Angka 2020. Sangatta: BPS Kabupaten Kutai Timur.

Burke, L., Selig, E., \& Spalding, M. (2002). Terumbu Karang yang Terancam di Asia Tenggara (Ringkasan untuk Indonesia). World Resources Institute, Amerika Serikat.

English, S. C., Wilkinson, V., \& Baker. (1994). Survey Manual for Tropical Marine Resources. Australia: Australian Institute of Marine Science.

Hill, J., \& Wilkinson, C. (2004). Methds for Ecological Monitoring of Coral Reef, Version 1; A Resource for Managers. Australia: Australian Institute of Marine Science.

Jompa, H., \& Pet-Soede, L. (2002). The Costal Fishery in East Kalimantan - A Rapid Assessment of Fishing Patterns, Status of Reff Habitat and Reff Fish Stock and Sosio-economic Caracteristics, Firs Draf- February 2002. Denpasar, Bali: WWF Indonesia-Wallacea Program.

Jubaedah, I., \& Anas, P. (2019). Dampak Pariwisata Bahari Terhadap Ekosistem Terumbu Karang di Perairan Nusa Penida, Bali. Jurnal Penyuluhan Perikanan Dan Kelautan, 13(1), 59-75.

Koroy, K., Alwi, D., \& Paraisu, N. G. (2020). Pengaruh laju sedimentasi terhadap tutupan terumbu karang di perairan Kota Daruba, Kabupaten Pulau Morotai. DEPIK Jurnal IImu-IImu Perairan, Pesisir Dan Perikanan, 9(2), 193-199.

Muqsit, A., Purnama, D., \& Ta'alidin, Z. (2016). Struktur Komunitas Terumbu Karang di Pulau Dua Kecamatan Enggano Kabupaten Bengkulu Utara. Jurnal Enggano, 1(1), 75-87.

Nontji, A. (2002). Laut Nusantara. Jakarta: Penerbit Djambatan.

Nybakken, J. W. (1992). Biologi Laut: Suatu Pendekatan Ekologis (terjemahan Muh. Eidman, Koesoebiono, Dietriech G.B, M. Hutomo, S. Sukarjo). Jakarta: PT. Gramedia.

Patty, S. I., \& Akbar, N. (2018). Kondisi Suhu, Salinitas, pH dan Oksigen Terlarut di Perairan Terumbu Karang Ternate, Tidore dan Sekitarnya. Jurnal IImu Kelautan Kepulauan, 1(2).

Purnawarman. (2020). Analisa Perubahan Garis Pantai. Bengkulu: Universitas Bengkulu.

Rani, D. A. S., Pratikto, W. A., \& Sambodo, K. (2015). Identifikasi Potensi Kawasan Sumberdaya Pulau Kangean Kabupaten Sumenep Madura sebagai Kawasan Wisata Bahari.

Rembet, U. N. W. J. (2012). Simbiosis Zooxanthellae dan Karang Sebagai Indikator Kualitas Ekosistem Terumbu Karang. Jurnal IImiah Platax, 1(1), 37-44. 
Rondonuwu, A. B., Unstain, N. W. J., Rembet, \& Ruddy Dj. Moningkey. John L. Tombokan, Alex D. Kambey, A. S. W. (2013). Ikan Karang Famili Chaetodontidae di Terumbu Karang Pulau Para Kecamatan Tatoareng Kabupaten Kepulauan Sangihe. Jurnal Ilmiah Platax. Manado: Universitas Sam Ratulangi.

Salim, D. (2012). Pengelolaan ekosistem terumbu karang akibat pemutihan (Bleaching) dan rusak. Jurnal Kelautan: Indonesian Journal of Marine Science and Technology, 5(2), 142-155.

Suharsono. (2008). Jenis-Jenis Karang di Indonesia. Jakarta: Pusat Penelitian dan Pengembangan Oseanogfi. LIPI.

Supriharyono. (2007). Konservasi Ekosistem Sumberdaya Hayati di Wilayah Pesisir dan Laut Tropis. Yogyakarta: Pustaka Pelajar.

Tanto, T. A., \& Kusumah, G. (2016). Kualitas Perairan Teluk Bungus Berdasarkan Baku Mutu Air Laut Pada Musim Berbeda. Maspari Journal, 8(2), 135-146.

Yulianda, F. (2007). Ekowisata Bahari sebagai Alternatif Pemanfaatan Sumber daya Pesisir Berbasis Konservasi. Makalah Disampaikan pada Seminar Sains 21 Februari 2007. Departemen MSP. FPIK. IPB. Bogor, 19. 